TITLE:

\title{
FERTILIZED SEA URCHIN EGGS AS AN INDICATORY MATERIAL FOR MARINE POLLUTION BIOASSAY, PRELIMINARY EXPERIMENTS
}

$\operatorname{AUTHOR(S):~}$

Kobayashi, Naomasa

CITATION:

Kobayashi, Naomasa. FERTILIZED SEA URCHIN EGGS AS AN INDICATORY MATERIAL FOR MARINE POLLUTION BIOASSAY, PRELIMINARY EXPERIMENTS. PUBLICATIONS OF THE SETO MARINE BIOLOGICAL LABORATORY 1971, 18(6): 379-406

\section{ISSUE DATE:}

1971-03-31

URL:

http://hdl.handle.net/2433/175652

RIGHT: 


\title{
FERTILIZED SEA URCHIN EGGS AS AN INDICATORY MATERIAL FOR MARINE POLLUTION BIOASSAY, PRELIMINARY EXPERIMENTS ${ }^{1)}$
}

\author{
NAOMASA KOBAYASHI \\ Biological Laboratory, Doshisha University, Kyoto
}

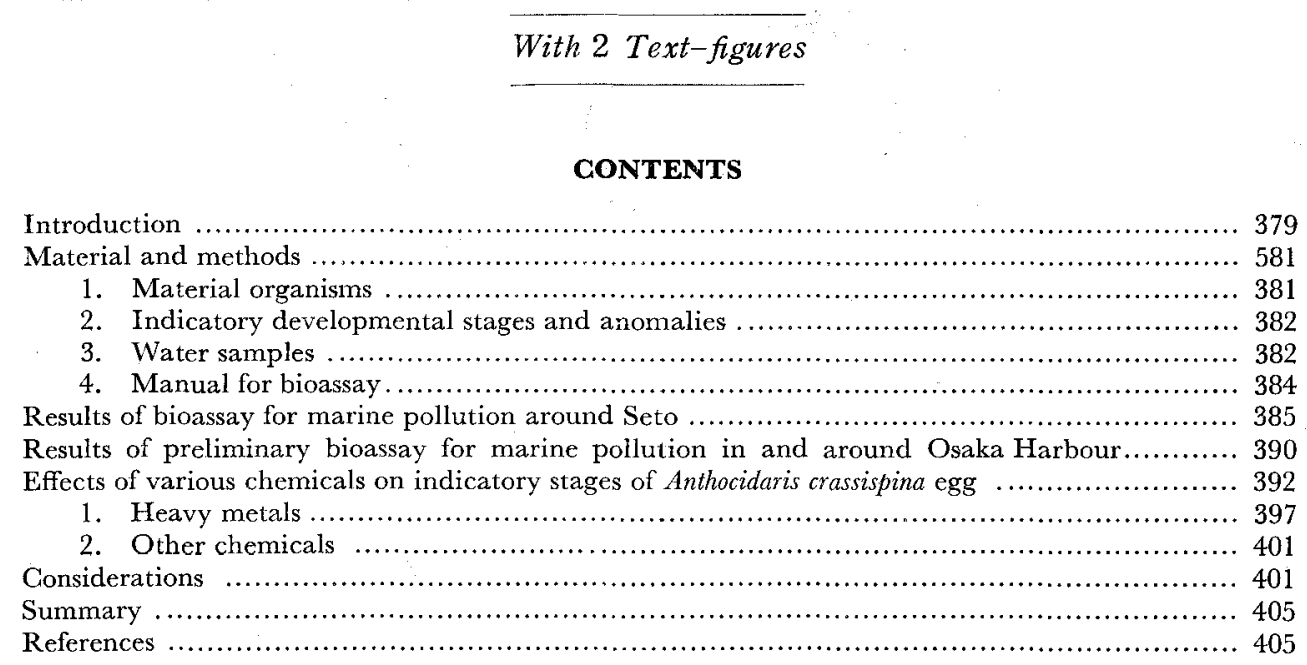

\section{Introduction}

The Seto Marine Biological Laboratory of Kyoto University, Shirahama, has started a series of preliminary surveys for a century observation of successions of littoral fauna and flora of Hatakejima Island (Text-fig. 1) since the spring of 1969. The island is the experimental field of the Seto Marine Biological Laboratory, situated in Tanabe Bay (Tokioka 1969), inhabited by several hundred species of tropical, subtropical and temperate-zone organisms because of its rich topographical diversity and thus has been for ages one of the most important places in Japan indispensable for reserches and education in marine biology. Meanwhile, the natural environment of the vicinity has been more or less damaged by over-collecting of littoral organisms and marine pollution caused by steadily increasing sewage, reclamation of coves, crowded rafts for oyster and pearl oyster culture and net-cages for fish rearing, etc. Evidently, it is now the very important moment when the efforts

1) Contributions from the Seto Marine Biological Laboratory, No. 539.

Publ. Seto Mar. Biol. Lab., XVIII (6), 379-406, 1971. (Article 26) 
should be concentrated in the conservation of nature of the sea to keep the island and the vicinity for the marine biological researches in future, and I have been asked by the staff of the Seto Marine Biological Laboratory to take a part of the above-mentioned long-term observations to check the water pollution.

There have been known many methods to judge the marine pollution. To marine biologists, however, it is very desirable to learn the actual effects of respective kinds of pollution, or pollutants on living organisms. For instance, the water contaminated with a certain toxic substance will induce some definable effects, very often

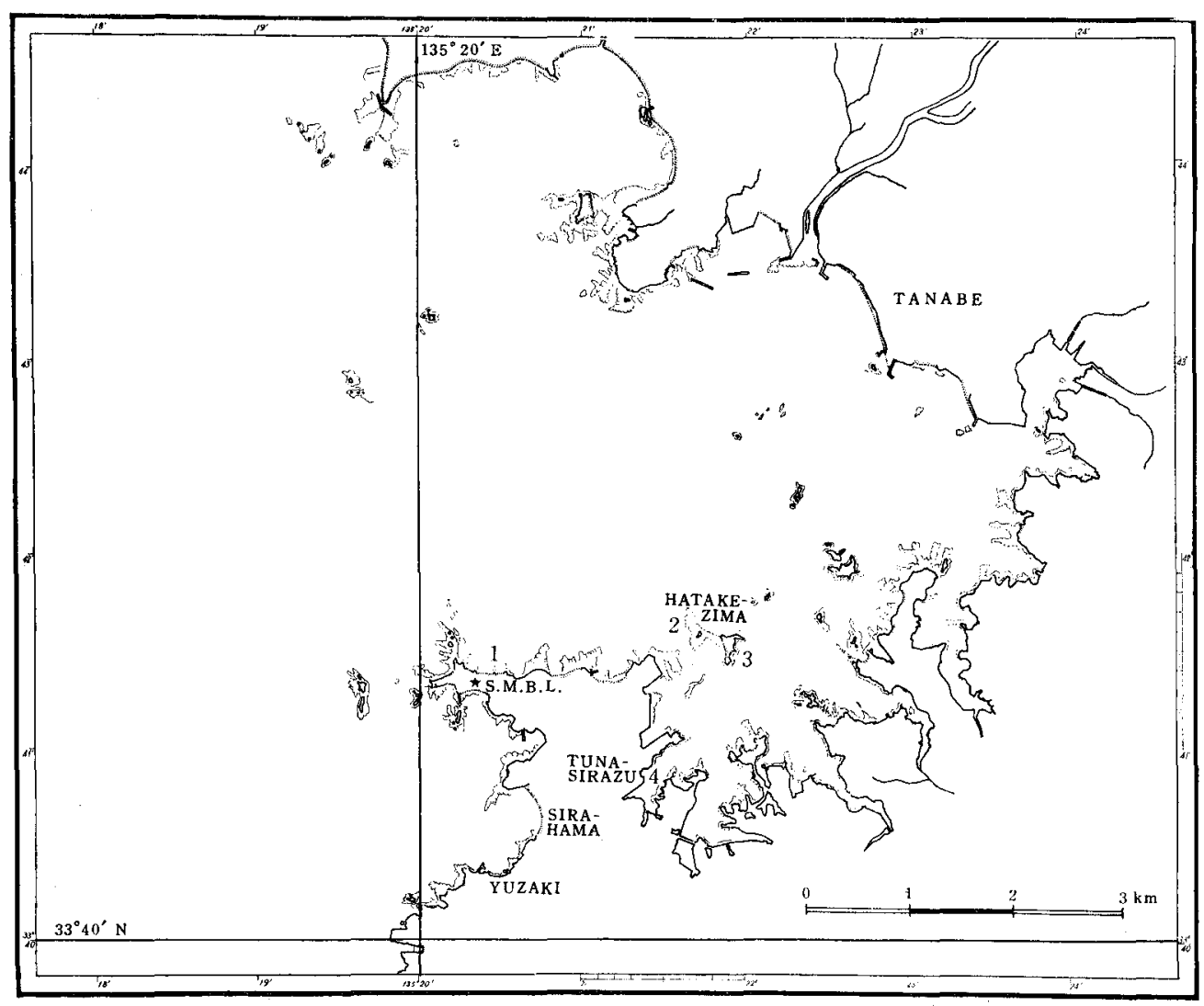

Fig. 1. Map of Tanabe Bay, showing the site of Hatakejima Island and 4 stations (1-4) for sampling the sea water. S.M.B.L.-Seto Marine Biological Laboratory.

leading to death, upon some organisms as shown in many cases of industrial pollutions. Even the very slight pollutions which can not be detected by chemical analyses will be cleared by bioassays. Especially, the bioassays will be appreciated highly when the toxic substances in the polluted water are unidentified. For bioassays, it is essential that the effects of pollution appear upon the material organisms simply and clearly, sharply, and constantly, the degree of effects can be estimated quantitatively, and the effects are unique to respective pollutants and organisms. At the same time, 
it is necessary that a sufficient number of material organisms are easily obtainable at any time. In these points, the sea urchin eggs may be one of the most suitable materials for the bioassay for marine pollution. Different anomalies induced by polluted waters containing various heavy metals, etc. at different developmental stages of sea urchin eggs and embryos may be available as indicators in bioassay.

So far as I am aware, such a method was reported first by WiLson and ARMSTrong (1951-1961) and then later by Окиво and Окиво (1962). The fertilization defined by the formation of fertilization membrane, cell division, gastrulation and many other developmental phenomena of sea urchin eggs are wrongly affected by various heavy metals, resulting in the occurrences of polyspermy and exogastrulation as already reported by various researchers (MacArthur 1924, WATERMan 1937, Sugryama 1950, etc.). These features are seemingly available as actual indicators in bioassay to measure the degree of marine pollution and to learn the effects of pollution on the reproduction of marine organisms. The present paper is, thus, to record the results of my preliminary experiments carried out to apply the above-mentioned bioassay to the water around Seto.

In addition, two control experiments were done respectively with the heavily polluted water of Osaka Harbour and with a series of chemicals, and their results are given preliminarily herewith.

\section{Material and methods}

1. Material organisms: Among many sea urchins in Japan, Hemicentrotus pulcherrimus (A. Agassiz), Anthocidaris crassispina (A. AgAssiz), Temnopleurus toreumaticus (LeSke) and Pseudocentrotus depressus (A. Agassiz) are most suitable to the material for pollution bioassay, because they are distributed abundantly and widely throughout the littoral waters of Japan except in her northern parts, and very easy to collect, further their breeding seasons succeed one another to cover nearly a whole year, though the exact season of respective urchins somewhat differs from place to place. The seasons of three urchins in the waters around the Seto Marine Biological Laboratory are given as follows; the average water temperatures are indicated in parentheses.

$\begin{array}{lll}\text { Hemicentrotus pulcherrimus : January to March, } & \left(14-16^{\circ} \mathrm{G}\right) \text {. } \\ \text { Anthocidaris crassispina : May to August, } & \left(20-28^{\circ} \mathrm{G}\right) \text {. } \\ \text { Pseudocentrotus depressus : October to November, } & \left(18-23^{\circ} \mathrm{G}\right) \text {. }\end{array}$

Temnopleurus toreumaticus which is found rather abundantly in some other places where Anthocidaris crassispina is rather scarce, can be used instead of the latter in its breeding season from July to August. But this urchin never occurs in the vicinity of Seto so abundantly nor commonly as to be used as the material for various experiments. The above-mentioned three urchins will be available as the material for pollution bioassay roughly all the year round at Seto, because these urchins can be fertilized and developed artificially at any time in their breeding seasons, and moreover the 
sensitivity of their eggs to various conditions inclusive of chemicals is nearly the same as has been noted by many researchers and also confirmed by my own experiences. 2. Indicatory developmental stages and anomalies: Text-figure 2, figs. 1-9: Then, the following stages of fertilization and development and their anomalies of urchin eggs are noted as indicators. In this paper, however, those of Anthocidaris crassispina are mainly referred to.

(a) Fertilization. There will occur the fertilization hardly or appear the polyspermy when the eggs are overmature, left untreated for a long time after they are shed, in bad conditions, or exposed to some toxic substances, etc. (CLARK 1936). In normal eggs, the elevation of the fertilization membrane (fig. 2) will follow the penetration of a sperm into an unfertilized egg (fig. 1),. Sometimes, however, the elevation of the fertilization membrane may be retarded and the eggs may retain the feature of an unfertilized egg till the cleavage begins.

(b) First cleavage. The fertilized egg divides into two cells of the same size in a certain time in normal conditions (fig. 3). However, the fertilized eggs will never divide when the eggs or sperms are in bad conditions or the sea water contains some toxic substances, etc.

(c) Polyspermic cleavage (Multi-cells). Penetration of several sperms into a single egg will bring about the polyspermy. Then the egg will divide into several cells and at the same time form a quite irregular configuration (fig. 4). Such multicell eggs are fated to die sooner or later, without recovering the normal development.

(d) Gastrula. The eggs developing successfully with repeated cleavages will attain blastula (fig. 5) in a certain time and swim out of the fertilization membrane, then the formation of spicules and the gastral cavity will begin to reach the gastrula stage (figs. 6, 8). There are a series of successive developmental changes on the way from blastula to gastrula, but it seems extremely difficult to check respective changes exactly. At present, only the gastrulation is available as a clearly definable significant change.

(e) Permanent blastula (Animalization). The development will be stopped at blastula when the sea water contains some toxic substances, etc.

(f) Exogastrula (Vegetalization). In the gastrulation, the archenteron will not be formed inside the embryo by invagination, but the tissue corresponding to the endoderm will grow up outside the embryo when the sea water contains toxic substances, such as some metallic ions, etc.; this is the so-called exogastrula (figs. 7, 9).

3. Water samples: It is planned that the bioassay is done with various species of sea urchins more than twice every season every year to see whether or not the sea water pollution around Hatakejima Island increases with time. Then, the water samples are to be collected from the following 4 stations.

(1) Running sea water in the Seto Marine Biological Laboratory, which is used in laboratory houses for experiments and also in the laboratory aqualium to keep many 

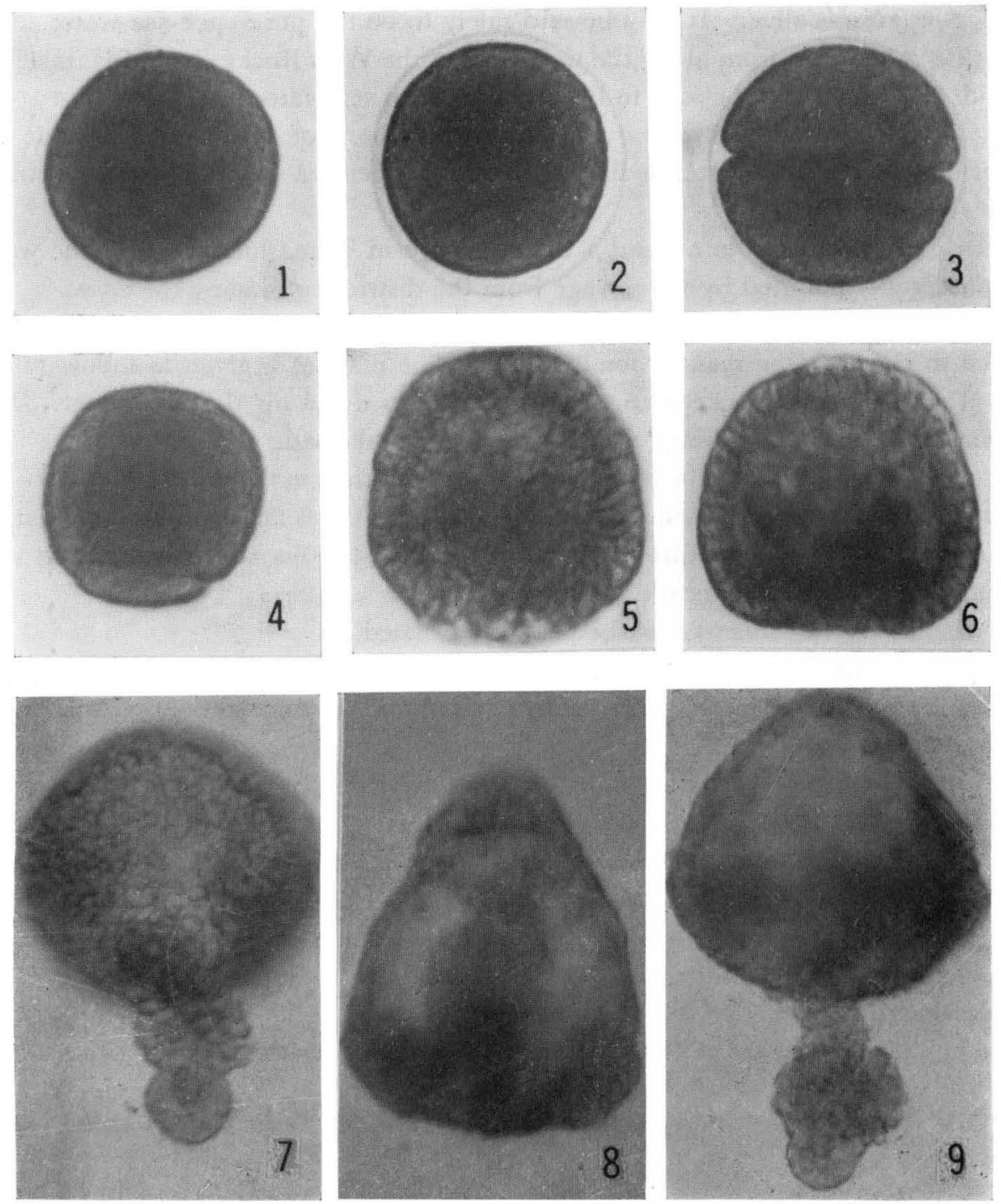

Fig. 2. Normal and abnormal features appeared in the fertilization and development of Anthocidaris crassispina eggs in the experiments, $\times 200$. Test water temp.: $28^{\circ} \mathrm{C}$. 1. Unfertilized (normal) egg, in the running sea water of Laboratory. 2. Formation of fertilization membrane (normal), $3 \mathrm{~min}$. after insemination, in the Laboratory water. 3. Two-cell stage (normal), $45 \mathrm{~min}$. after insemination, in the Laboratory water. 4. Multi-cells (polyspermy), $45 \mathrm{~min}$. after insemination, in the water from the land side of Hatakejima Island. 5. Late blastula (normal), $8 \mathrm{hrs}$. after insemination, in the Laboratory water. 6. Middle gastrula (normal), $12 \mathrm{hrs}$. after insemination, in the Laboratory water. 7. Exogastrula, $12 \mathrm{hrs}$. after insemination, in the water from the land side of Hatakejima Island. 8. Late pyramid larva (normal), 16 hrs. after insemination, in the Laboratory water. 9. Exogastrula, $16 \mathrm{hrs}$. after insemination, in the water from the land side of Hatakejima Island. 
marine organisms alive. It may be said safely to be the pure open-sea water.

(2) The water from along the west edge of the West Rocky Reef of Hatakejima Island; the water may be said to be the pure open-sea water.

(3) The water from along the east rocky shore of Hatakejima Island; the water may be said to be intermediate between the open-sea water and the inlet water somewhat polluted.

(4) The water from around a floating stage in Tsunashirazu Gove; the water is considerably polluted by the sewage from the district embracing the cove.

4. Manual for bioassay: To maintain the long-term continual observations, it is essential to establish the manual for bioassay. The manual is given as follows:

(1) A metallic bucket can never be used to draw up the test water. It is recommended to use a strictly cleaned bucket or tank made of plastics.

(2) The test water is to be collected at noon, then in the lowest water, around the spring tide and to be used as soon as possible, within one day at the maximum. The water under such conditions seems to be in a state most evenly mingled with pollutants because of the local tidal currents.

(3) Every instrument must be perfectly cleaned.

(4) Sea urchins are to be collected when they are at the peak of maturity just before or after the spring tide (Kobayasmi 1969), and they are to be used within 1-2 days after collection.

(5) Three to five females and 2-3 males are to be collected to supply enough eggs for bioassay at respective examinations.

(6) Eggs are to be obtained by the current $\mathrm{KCl}$-method, washed several times with sea water, and to be used as soon as possible, within 1 hour at the maximum. The amount of eggs thus discharged seems to reflect the grade of gonadal maturity of treated urchins, which is noted as full ripe: +++ or ripe: ++ . No immature or over-mature eggs are to be contained in any batch.

(7) The sperms are to be obtained from testes taken out of the test, within 1 hour after the operation.

(8) The standard sperm density for insemination is about 1 dry sperm: 1,000 sea water.

(9) If necessary, the preliminary check of eggs is to be done to see if the fertilization membrane is elevated in 3 minutes after insemination on over $85 \%$ of them and if the well synchronized first cleavage occurs on over $80 \%$ of them.

(10) The glass finger bowl used is $5 \mathrm{~cm}$ in diamater and $3 \mathrm{~cm}$ in depth, and to be covered with a watch glass.

(11) Eggs are to be sacttered in a single layer on the bottom of a finger bowl filled with the test water, then to be inseminated within 2-3 minutes after this treatment.

(12) The percent of eggs with the elevated fertilization membrane to the total eggs experimented with is to be read 3 minutes after insemination, while the rate and state of the first cleavage are to be checked at some adequate time, that will 
differ with temperature and some other factors. One thousand eggs are to be examined at a time.

(13) Only swimming gastrular embryos are to be examined at a certain time, those deposited on the bottom being excluded. One thousand embryos are to be checked at a time.

\section{Results of bioassay for marine pollution around Seto}

The urchin eggs inseminated in respective test water after the manual mentioned above were fixed at respective given time with $5 \%$ formaldehyde to read the percentages of eggs or embryos, with the elevated fertilization membrane, in the undividing one-cell state, in the normal two-cell state, in the multi-cell state caused by

Table 1. Results of the first experiment with eggs of Hemicentrotus pulcherrimus. Date: Feb. 21 and 22,1970 . Wind: NW 2. Test water temperature: $17-20^{\circ} \mathrm{C}$ (warmed).

\begin{tabular}{|c|c|c|c|c|c|c|c|}
\hline \multirow{2}{*}{$\begin{array}{l}\text { Indicatory } \\
\text { states }\end{array}$} & \multirow{2}{*}{$\begin{array}{l}\text { Time of } \\
\text { observation* }\end{array}$} & \multicolumn{6}{|c|}{ Running sea water of laboratory } \\
\hline & & $\begin{array}{l}\text { No. } 1 \\
+++\end{array}$ & $\begin{array}{c}\text { No.2 } \\
++(+)\end{array}$ & $\begin{array}{c}\text { No.3 } \\
++\end{array}$ & $\begin{array}{c}\text { No. } 4 \\
++\end{array}$ & $\begin{array}{c}\text { No. } 5 \\
++\end{array}$ & $\begin{array}{r}\text { No. } 6 \\
++(+)\end{array}$ \\
\hline formation of fertilization & hr. min. & $\%$ & $\%$ & $\%$ & $\%$ & $\%$ & $\%$ \\
\hline membrane & $0: 03$ & 98.2 & 98.5 & 98.6 & 98.3 & 96.4 & 99.1 \\
\hline one cell & \multirow{3}{*}{$1: 30$} & 2.0 & 4.2 & 2.8 & 1.7 & 2.5 & 0.9 \\
\hline two cells & & 97.1 & 95.2 & 96.4 & 97.1 & 96.1 & 98.3 \\
\hline multi-cells (polyspermy) & & 0.9 & 0.6 & 0.8 & 1.2 & 1.4 & 0.8 \\
\hline permanent blastula & \multirow{3}{*}{$24: 00$} & 0.1 & 0.1 & 0.0 & 0.2 & 0.2 & 0.3 \\
\hline gastrula & & 99.8 & 99.6 & 99.8 & 99.7 & 99.8 & 99.6 \\
\hline exogastrula & & 0.1 & 0.3 & 0.2 & 0.1 & 0.0 & 0.1 \\
\hline
\end{tabular}

* After insemination. No. 1 to No. 6 are batch numbers of eggs.

+++ shows a full ripe state and ++ a ripe state of the gonad.

polyspermy, in permanent blastula, in normal gastrula, or in an abnormal exogastrula. Then, the degree of the water pollution may be estimated on these percentages.

A. February 21 and 22, 1970 (full moon on Feb. 20). Material urchin:' Hemicentrotus pulcherrimus.

The experiment was carried out in a room heated to accelerate the development of fertilized eggs, which unless will take more than 48 hours to attain gastrulation at $10-15^{\circ} \mathrm{C}$. The room temperature was regulated at or below $20^{\circ} \mathrm{C}$ to prevent the abnormal development which will occur frequently at higher temperature over $21^{\circ} \mathrm{C}$.

This time, the experiment was but only a preliminary or control one, then the bioassay was done with only the running sea water of the laboratory. As seen in Table 1, the formation of fertilization membrane and the regular cleavages were done 
both at very high rates in every batch of eggs. Some multi-cells were seen, but this might be a property unique to this urchin. Further, the gastrulation occurred almost perfectly, with little anomalies. The laboratory water in which the fertilization, cleavages and gastrulation are quite normal may be regarded as unpolluted. And then, hereafter, the water of the laboratory may be regarded as the control water for the assay.

B. May 21 and 22, 1970 (full moon on May 21). Material urchin: Anthocidaris crassispina.

Three water samples were experimented with this time, i.e. the laboratory water, the water from the open-sea side of Hatakejima Island and that from the east land side of the island. The polyspermy was somewhat remarkable in every water sample

Table 2. Results of the second experiment with eggs of Anthocidaris crassispina. Date: May 21 and 22,1970 , Wind: 0 . Test water temperature: $20^{\circ} \mathrm{C}$.

\begin{tabular}{|c|c|c|c|c|c|c|c|c|c|c|}
\hline \multirow{2}{*}{$\begin{array}{l}\text { Indicatory } \\
\text { states }\end{array}$} & \multirow{2}{*}{$\begin{array}{l}\text { Time of } \\
\text { observ- } \\
\text { ation* }\end{array}$} & \multicolumn{3}{|c|}{$\begin{array}{l}\text { Running sea water } \\
\text { of laboratory }\end{array}$} & \multicolumn{3}{|c|}{$\begin{array}{l}\text { Water from open- } \\
\text { sea side of } \\
\text { Hatakejima }\end{array}$} & \multicolumn{3}{|c|}{$\begin{array}{l}\text { Water from land } \\
\text { side of } \\
\text { Hatakejima }\end{array}$} \\
\hline & & $\begin{array}{l}\text { No. } 1 \\
+++1\end{array}$ & $\begin{array}{l}\text { No. } 2 \\
++\end{array}$ & $\begin{array}{l}\text { No. } 3 \\
++(t)\end{array}$ & No. 1 & No. 2 & No. 3 & No. 1 & No. 2 & No. 3 \\
\hline formation of & & & $\%$ & $\%$ & $\%$ & $\%$ & $\%$ & $\%$ & $\%$ & $\%$ \\
\hline membrane & $0: 03$ & 98.3 & 93.1 & 98.4 & 98.5 & 92.0 & 97.8 & 94.9 & 90.1 & 93.5 \\
\hline one cell & \multirow{3}{*}{$1: 30$} & 1.2 & 2.1 & 1.3 & 0.8 & 1.9 & 0.9 & 12.7 & 14.6 & 6.7 \\
\hline two cells & & 98.2 & 86.5 & 95.5 & 97.1 & 87.1 & 96.2 & 82.1 & 70.3 & 88.1 \\
\hline $\begin{array}{l}\text { multi-cells } \\
\text { (polyspermy) }\end{array}$ & & 0.6 & 11.4 & 3.2 & 2.1 & 11.0 & 2.9 & 5.2 & 15.1 & 5.2 \\
\hline permanent blastula & \multirow{3}{*}{$24: 00$} & 1.2 & 5.7 & 2.1 & 3.2 & 6.1 & 1.8 & 4.6 & 8.7 & 3.9 \\
\hline gastrula & & 98.6 & 93.9 & 97.6 & 96.5 & 93.1 & 97.7 & 94.5 & 90.1 & 95.3 \\
\hline exogastrula & & 0.2 & 0.4 & 0.3 & 0.3 & 0.8 & 0.5 & 0.9 & 1.2 & 0.8 \\
\hline
\end{tabular}

* After insemination. No. 1 to No. 3 are batch numbers of eggs.

++ shows a full ripe state and ++ a ripe state of the gonad.

(Table 2), even in the laboratory water, especially in No. 2 batch. However, there were hardly differences between the laboratory water and that from the open-sea side of Hatakejima Island. On the other hand, in the water from the east land side of the island the polyspermy occurred more frequently, and the rates of regular fertilization and cleavages were somewhat lower; the tendency of higher occurrences of anomalies was seen also in the later developmental stages. The rates of successful fertilization and regular development, somewhat lower than in next examination, in the laboratory water were probably attributable to the fact that Anthocidaris crassispina was at that time in the beginning of its breeding season, and then the lower rates were caused by unsatisfactory conditions of urchin eggs used but not by the sea water assayed. In general, there was no sign of pollution in the laboratory water and that 
from the open-sea side of Hatakejima Island, but the pollution of some degree must have occurred along the land side of the island.

C. July 21, 1970 (full moon on July 18). Material urchin: Antocidaris crassispina.

One more water sample, the water collected near the floating stage in Tsunashirazu Cove, not far from Hatakejima Island, was added for assay for the reason that the water in that cove must be polluted much more heavily by accumulation of home and hotel sewage and wastes from mooring boats and rearing or cultivation farms of fish or shell-fish. This time again, the rates of regular cleavages were unusually low in No. 3 batch (Table 3). However, the results of the assay were hardly different between the laboratory water and that from the open-sea side of Hatakejima Island. On the other hand, in the water from the land side of the island and that from Tsunashirazu Cove, especially in the latter, the rates of regular cleavages and embryonal developments were constantly lower than in the above-mentioned two. It may be concluded that the water was slightly polluted on the land side of the island and considerably in Tsunashirazu Cove.

D. August 18 and 19, 1970 (full moon on Aug. 17). Material urchin: Anthocidaris crassispina.

The assay was repeated in the same summer season, because the influx of the oceanic water will be least and the polluted surface water of coves will be extended around Hatakejima Island in this season when the monsoon from the north-west quite dies out and the wind from the south-southeast predominates. At first, Mespilia globulus which was in its breeding season was used for assay, however it was soon found that the urchin did not fit the purpose because it was too sensitive to the environmental factors to be used for observations without perfect controlling of experimental conditions. Thus, Anthocidaris crassispina was used as the material, though it was near the end of its breeding season in late August. Then, inevitably, the rates of fertilization membrane formation and regular cleavages of eggs were much lowered. Nevertheless, it was shown clearly as seen in Table 4, that the rates of fertilization membrane formation and regular cleavages were very similar between the laboratory water and that from the open-sea side of Hatakejima Island as before, while the rates were lower in other two water samples, especially in the water from Tsunashirazu Cove.

In general, throughout the results of the above-mentioned four experiments, any signs of biologically significant pollution have seemingly not yet been observed in the laboratory water and the water from the open-sea side of Hatakejima Island, but a considerable pollution is already definable in the water from the land side of the island and the water from Tsunashirazu Cove, especially in the latter. Although the details are not yet known about the actual effects of the water from respective stations upon other marine organisms, it is clear that the water pollution around Hatakejima Island differes distinctly from place to place, and that the efforts for natural conser- 
Table 3. Results of the third experiment with eggs of Anthocidaris crassispina. Date: July 21, 1970. Wind: 0 Test water temperature: $28^{\circ} \mathrm{C}$

\begin{tabular}{|c|c|c|c|c|c|c|c|c|c|c|c|c|c|}
\hline \multirow{2}{*}{$\begin{array}{l}\text { Indicatory } \\
\text { states }\end{array}$} & \multirow{2}{*}{$\begin{array}{l}\text { Time of } \\
\text { observation* }\end{array}$} & \multicolumn{3}{|c|}{$\begin{array}{l}\text { Running sea water of } \\
\text { laboratory }\end{array}$} & \multicolumn{3}{|c|}{$\begin{array}{l}\text { Water from open-sea side } \\
\text { of Hatakejima }\end{array}$} & \multicolumn{3}{|c|}{$\begin{array}{l}\text { Water from land side of } \\
\text { Hatakejima }\end{array}$} & \multicolumn{3}{|c|}{$\begin{array}{l}\text { Sea water from } \\
\text { Tsunashirazu cove }\end{array}$} \\
\hline & & $\begin{array}{l}\text { No. } 1 \\
++\end{array}$ & $\begin{array}{l}\text { No. } 2 \\
+++\end{array}$ & $\begin{array}{l}\text { No. } 3 \\
+++\end{array}$ & No. 1 & No. 2 & No. 3 & No. 1 & No. 2 & No. 3 & No. 1 & No. 2 & No. 3 \\
\hline formation of & hr. $\min$. & $\%$ & $\%$ & $\%$ & $\%$ & $\%$ & $\%$ & $\%$ & $\%$ & $\%$ & $\%$ & $\%$ & $\%$ \\
\hline membrane & $0: 03$ & 99.8 & 99.7 & 87.2 & 99.6 & 98.2 & 86.5 & 98.2 & 97.6 & 84.2 & 93.2 & 95.1 & 82.3 \\
\hline one cell & \multirow{3}{*}{$0: 45$} & 18.1 & 7.2 & 20.1 & 19.1 & 12.2 & 21.3 & 23.1 & 17.2 & 32.1 & 21.0 & 23.1 & 37.1 \\
\hline two cells & & 81.9 & 92.8 & 79.7 & 80.9 & 87.6 & 78.5 & 76.7 & 82.2 & 67.3 & 75.7 & 76.0 & 60.6 \\
\hline $\begin{array}{l}\text { multi-cells } \\
\text { (polyspermy) }\end{array}$ & & 0.0 & 0.0 & 0.2 & 0.0 & 0.2 & 0.2 & 0.2 & 0.6 & 0.6 & 3.3 & 0.9 & 2.3 \\
\hline $\begin{array}{l}\text { permanent } \\
\text { blastula }\end{array}$ & \multirow{3}{*}{$17: 00$} & 1.1 & 1.2 & 2.1 & 1.0 & 2.1 & 2.3 & 3.1 & 3.4 & 4.1 & 4.3 & 4.1 & 4.6 \\
\hline gastrula & & 98.9 & 98.6 & 97.6 & 98.7 & 97.7 & 97.6 & 95.7 & 96.1 & 95.3 & 93.4 & 95.1 & 94.5 \\
\hline exogastrula & & 0.0 & 0.2 & 0.3 & 0.3 & 0.2 & 0.1 & 1.2 & 0.5 & 0.6 & 2.3 & 0.8 & 0.9 \\
\hline
\end{tabular}

* After insemination., No. 1 to No. 3 are batch numbers of eggs.

$++t$ shows a full ripe state and ++ a ripe state of the gonad. 
Table 4. Results of the fourth experiment with eggs of Anthocidaris crassispina.

Date: Aug. 18 and 19, 1970. Wind: 0. Test water temperature: $28^{\circ} \mathrm{C}$.

\begin{tabular}{|c|c|c|c|c|c|c|c|c|c|c|c|c|c|}
\hline \multirow{2}{*}{$\begin{array}{l}\text { Indicatory } \\
\text { states }\end{array}$} & \multirow{2}{*}{$\begin{array}{l}\text { Time of } \\
\text { observation * }\end{array}$} & \multicolumn{3}{|c|}{$\begin{array}{l}\text { Running sea water of } \\
\text { laboratory }\end{array}$} & \multicolumn{3}{|c|}{$\begin{array}{l}\text { Water from open-sea side } \\
\text { of Hatakejima }\end{array}$} & \multicolumn{3}{|c|}{$\begin{array}{l}\text { Water from land side of } \\
\text { Hatakejima }\end{array}$} & \multicolumn{3}{|c|}{$\begin{array}{l}\text { Sea water from } \\
\text { Tsunashirazu cove }\end{array}$} \\
\hline & & $\begin{array}{l}\text { No. 1 } \\
+(+)\end{array}$ & $\begin{array}{l}\text { No. } 2 \\
+(+) \\
\end{array}$ & $\begin{array}{r}\text { No. } 3 \\
++(+)\end{array}$ & No. 1 & No. 2 & No. 3 & No. 1 & No. 2 & No. 3 & No. 1 & No. 2 & No. 3 \\
\hline formation of & hr. min. & $\%$ & $\%$ & $\%$ & $\%$ & $\%$ & $\%$ & $\%$ & $\%$ & $\%$ & $\%$ & $\%$ & $\%$ \\
\hline membrane & $0: 03$ & 80.4 & 82.1 & 91.2 & 82.7 & 83.4 & 90.1 & 77.1 & 81.0 & 84.1 & 68.2 & 69.1 & 75.3 \\
\hline one cell & \multirow{3}{*}{$0: 45$} & 19.6 & 18.8 & 9.6 & 17.4 & 16,8 & 9.8 & 23.3 & 22.4 & 17.3 & 34.5 & 31.3 & 28.6 \\
\hline two cells & & 80.3 & 81.0 & 90.0 & 82.4 & 82.9 & 89.9 & 76.0 & 77.1 & 82.1 & 64.6 & 67.6 & 70.6 \\
\hline $\begin{array}{l}\text { multi-cells } \\
\text { (polyspermy) }\end{array}$ & & 0.1 & 0.2 & 0.4 & 0.2 & 0.3 & 0.3 & 0.7 & 0.5 & 0.6 & 0.9 & 1.1 & 0.8 \\
\hline $\begin{array}{l}\text { permanent } \\
\text { blastula }\end{array}$ & \multirow{3}{*}{$12: 00$} & 1.2 & 1.1 & 0.7 & 1.2 & 1.2 & 1.0 & 2.3 & 2.9 & 2.0 & 2.5 & 3.6 & 2.8 \\
\hline gastrula & & 98.8 & 98.8 & 99.3 & 98.8 & 98.6 & 98.9 & 97.5 & 96.9 & 97.6 & 96.7 & 95.8 & 96.7 \\
\hline exogastrula & & 0.0 & 0.1 & 0.0 & 0.0 & 0.2 & 0.1 & 0.2 & 0.2 & 0.4 & 0.8 & 0.6 & 0.5 \\
\hline
\end{tabular}

* After insemination., No. 1 to No. 3 are batch numbers of eggs.

+++ shows a full ripe state and ++ a ripe state of the gonad. 
vation around Hatakejima Island will promise a bright prospect at least on the opensea side of the island.

\section{Results of preliminary bioassay for marine pollution in and around Osaka Harbour}

It had been a matter of interest to apply the above-mentioned manual of bioassay to the water of Osaka Bay which is one of the heavily polluted waters in the western part of this country. Fortunately, I had a chance to obtain two heavily polluted water samples from Osaka Bay, one collected near the floating stage of the Osaka Maritime Safety Station in Osaka Harbour and the other at a float in the estuary of the River Kizu. As the salinity was too low in these water samples to allow the fertilization and further development of sea urchin eggs, it was essential to find out some adequate way to make these phenomena possible. From a biological point of view, it seemed very difficult to judge what way was the most reasonable. Thus, two series of experiments were planned, as the preliminary ones, with two batches of Anthocidaris crassispina eggs and using the laboratory water as the standard control. Unfortunately, however, Anthocidaris crassispina was near the closing time of its breeding season on August 18 when the experiments were carried out, then inevitably the rates of fertilization membrane formation and regular cleavages were considerably lower even in the standard laboratory water.

First, the salinity adjustment of the test water samples which were about half as saline as the laboratory water (see p. 392), was made in the following two ways: (1) The salinity was raised up to the level of the laboratory water by adding some amount of Jamarin, a commercial mixture for artificial sea water.

(2) The salinity was recovered by condensation by boiling the water for about 30 minutes.

Besides the running sea water of the laboratory (Control 1), the artificial sea water made from Jamarin (Control 2) and the boiled laboratory water (Control 3) were experimented with to see the effects of the above-mentioned treatments of the test water.

As Wrison and Armstrong (1954) stated already that sea urchin embryos reared in the heated water or artificial sea water were generally inferior to those reared in natural sea water, the rates of successful fertilization and normal development were slightly or considerably lower in respectively the boiled laboratory water and the artificial sea water (Table 5).

In the water samples from Osaka Harbour and the estuary of the River Kizu adjusted by adding Jamarin, the fertilization and further development of eggs were achieved but only in insignificant numbers, much smaller than in the artificial sea water (Gontrol 2). Moreover, the first cleavage took place about one hour after the insemination, about 15 minutes later than in the controls and the further develop- 
Table 5. Results of a preliminary bioassay of the heavily polluted water from Osaka Bay, experimented with Anthocidaris crassispina eggs. Date: August 18, 1970. Test water temperature: $28^{\circ} \mathrm{C}$.

\begin{tabular}{|c|c|c|c|c|c|c|c|c|c|c|c|c|c|c|c|}
\hline \multirow{2}{*}{$\begin{array}{l}\text { Indicatory } \\
\text { states }\end{array}$} & \multirow{2}{*}{$\begin{array}{c}\text { Time of } \\
\text { observ } \\
\text { ation* }\end{array}$} & \multicolumn{2}{|c|}{$\begin{array}{l}\text { Running sea } \\
\text { water of lab. }\left(\mathrm{C}_{1}\right)\end{array}$} & \multicolumn{2}{|c|}{$\begin{array}{l}\text { Water from** } \\
\text { Osaka Harbour }\end{array}$} & \multicolumn{2}{|c|}{$\begin{array}{l}\text { Water from** } \\
\text { Kizu Estuary }\end{array}$} & \multicolumn{2}{|c|}{$\begin{array}{l}\text { Artificial sea } \\
\text { water }\left(\mathrm{C}_{2}\right)\end{array}$} & \multicolumn{2}{|c|}{$\begin{array}{l}\text { Boiled Harbour } \\
\text { water } * * *\end{array}$} & \multicolumn{2}{|c|}{$\begin{array}{l}\text { Boiled Estuarine } \\
\text { water } * * *\end{array}$} & \multicolumn{2}{|c|}{$\begin{array}{l}\text { Boiled lab. } \\
\text { water }\left(\mathrm{C}_{3}\right)\end{array}$} \\
\hline & & $\begin{array}{l}\text { No. } 1 \\
+(t)\end{array}$ & $\begin{array}{c}\text { No. } 2 \\
++(+)\end{array}$ & No. 1 & No. 2 & No. 1 & No. 2 & No. 1 & No. 2 & No. 1 & No. 2 & No. 1 & No. 2 & No. 1 & No. 2 \\
\hline $\begin{array}{l}\text { formation of } \\
\text { fertilization } \\
\text { membrane }\end{array}$ & $\begin{array}{c}\text { hr. } \min . \\
0: 03\end{array}$ & $\begin{array}{c}\% \\
75.3\end{array}$ & 76.8 & $\begin{array}{r}\% \\
13.5\end{array}$ & 11.3 & $\begin{array}{c}\% \\
7.3\end{array}$ & 5.9 & 63.5 & $\begin{array}{r}\% \\
68.3\end{array}$ & 74.2 & 72.1 & $\begin{array}{r}\% \\
70.5\end{array}$ & 71.2 & 74.8 & 74.2 \\
\hline one cell & \multirow{3}{*}{$\begin{array}{c}0: 45(\mathrm{C}) \\
1: 00\end{array}$} & 33.1 & 27.3 & 87.5 & 92.7 & 93.7 & 94.6 & 40.2 & 35.7 & 34.2 & 31.3 & 42.5 & 31.8 & 34.1 & 29.3 \\
\hline two cells & & 66.8 & 72.5 & 11.3 & 6.5 & 5.6 & 4.8 & 59.6 & 64.1 & 65.5 & 68.3 & 57.3 & 67.9 & 65.7 & 70.5 \\
\hline $\begin{array}{r}\text { multi-cells } \\
\text { (po yspermy) }\end{array}$ & & 0.1 & 0.2 & 1.2 & 0.8 & 0.7 & 0.6 & 0.2 & 0.2 & 0.3 & 0.4 & 0.2 & 0.3 & 0.2 & 0.2 \\
\hline $\begin{array}{l}\text { permanent } \\
\text { blastula }\end{array}$ & \multirow{3}{*}{$12: 00$} & 1.1 & 0.8 & 72.4 & 80.5 & 78.3 & 87.3 & 6.7 & 5.4 & 2.7 & 3.6 & 3.6 & 3.3 & 2.4 & 1.8 \\
\hline gastrula & & 98.9 & 99.2 & 27.4 & 19.3 & 21.4 & 12.4 & 93.3 & 94.5 & 97.2 & 96.2 & 96.3 & 96.5 & 97.5 & 98.1 \\
\hline exogastrula & & 0.0 & 0.0 & 0.2 & 0.2 & 0.3 & 0.3 & 0.0 & 0.1 & 0.1 & 0.2 & 0.1 & 0.2 & 0.1 & 0.1 \\
\hline
\end{tabular}

* After insemination. The check of the first cleavage was made 45 minutes after insemination in controls but 1 hour after in the test water. No. 1 and No. 2 are batch numbers of eggs. $++(+)$ shows a state between full ripe and ripe and $+(+)$ a state of the gonad just before ripe.

** Density recovered by addition of Jamarin to the level of Controls 1 and 2 .

*** Density recovered by evaporation to the level of Control 3. 
ments were also much delayed, resulting in higher percentage of permanent blastula. The biological conditions seemed worse in the water from the estuary of the River Kizu than in the water from Osaka Habour.

On the other hand, the rates of fertilization and normal developments were much improved, raised nearly to the level of the boiled laboratory water (Control 3), in the water samples condensed by boiling. In this treatment, too, the pollution seemed progressed in the estuary of the River Kizu than in Osaka Harbour.

\section{Effects of various chemicals on indicatory stages of Anthocidaris crassispina eggs}

It is obvious that various pollutants will affect differently the indicatory developmental stages of sea urchin eggs at different concentrations in the sea water. As the most important solutes in the sea water are the natural salts in the sea, their collective concentration, the salinity, must be the first matter to be checked; and this was done simply by measuring the density by a hydrometer to save time. Then, a check was made on the water samples from respective stations in Tanabe Bay on August 19, when the two water samples from Osaka Bay were tested together. In the diluted water $\left(\sigma_{15}: 1.012\right.$ or 1.014 at $\left.15^{\circ} \mathrm{C}\right)$, no eggs of Anthocidaris crassispina were fertilized; in the water of 1.016 only $6.2 \%$ of treated eggs were fertilized. On the more saline side, eggs were never fertilized in the water of 1.034 or 1.036 . The density of respective water samples from Tanabe Bay on that day was 1.02417 for the standard laboratory water, 1.02512 for the water from the open-sea side of Hatakejima Island, 1.02421 for the water from the land side of the island, and 1.02103 for the water from Tsunashirazu Cove. The density of two water samples from Osaka Bay was 1.01391 for the water from the harbour and 1.01284 for the water from the estuary of the River Kizu. Thus the density of the water of those samples must be raised up to 1.02410 by the treatments mentioned previously. The rates of respective indicatory developmental states of eggs of the same urchin in the range of density from 1.018 to 1.032 in that season are shown in Table 6 . It may be seen that no significant developmental anomalies occur in the range from 1.020 to 1.028. On the other hand, the accumulated data of the salinity at several stations in Tanabe Bay, observed in students' marine biology courses (1955 and 1961-1970, thanks to Dr. Sh. Fuse of the laboratory for compliation), show that the salinity retains steadily the range of 32.00 to $34.00 \%$ (31.42\% near the estuary of the River Aizu and 36.00\% near the bottom of a certain small basin) even in coves unless there is an effect of heavy rain fall. For these reasons, so far as the coaction of pollutants and the salinity is not discussed, the density or salinity of the test water is not referred to in respective bioassay.

Then turning to the pollutants of the sea water, the effects of various chemicals referred to in the Japanese "Standards of water quality" upon the indicatory develop- 
Table 6. Rates of indicatory developmental stages of Anthocidaris crassispina eggs at different sea water densities $(\sigma: 1.018-1.032)$. Date: August 19, 1970. Test water temperature: $28^{\circ} \mathrm{C}$.

\begin{tabular}{|c|c|c|c|c|c|c|c|c|c|c|c|c|c|}
\hline \multirow{2}{*}{$\begin{array}{l}\text { Indicatory } \\
\text { states }\end{array}$} & \multirow{2}{*}{$\begin{array}{l}\text { Time of } \\
\text { observ.* }\end{array}$} & \multicolumn{3}{|c|}{$\sigma_{15}: 1.018$} & \multicolumn{3}{|c|}{1.020} & \multicolumn{3}{|c|}{1.022} & \multicolumn{3}{|c|}{$1.024(\mathrm{C})$} \\
\hline & & $\begin{array}{c}\text { No. } 1 \\
++\end{array}$ & $\begin{array}{l}\text { No. } 2 \\
+(+)\end{array}$ & $\begin{array}{l}\text { No. } 3 \\
+++\end{array}$ & No. 1 & No. 2 & No. 3 & No. 1 & No. 2 & No. 3 & No. 1 & No. 2 & No. 3 \\
\hline $\begin{array}{l}\text { Formation of } \\
\text { fertiliz. memb. }\end{array}$ & $\begin{array}{l}\text { hr. min. } \\
0: 03\end{array}$ & $68.3^{\%}$ & $67.4^{\%}$ & $70.3^{\%}$ & $82.6^{\%}$ & $80.3^{\%}$ & $88.8^{\%}$ & $84.1^{\%}$ & $83.0^{\%}$ & $91.8^{\%}$ & $84.2^{\%}$ & $82.3^{\%}$ & $92.1^{\%}$ \\
\hline one cell & \multirow{3}{*}{$0: 45$} & 35.0 & 36.2 & 32.0 & 19.5 & 20.1 & 12.4 & 16.7 & 17.7 & 9.6 & 16.8 & 18.2 & 9.7 \\
\hline two cells & & 64.2 & 63.2 & 67.3 & 80.2 & 79.4 & 87.2 & 83.2 & 82.3 & 90.0 & 83.1 & 81.5 & 90.2 \\
\hline $\begin{array}{l}\text { multi-cells } \\
\text { (polyspermy) }\end{array}$ & & 0.8 & 0.6 & 0.7 & 0.3 & 0.5 & 0.4 & 0.1 & 0.0 & 0.4 & 0.1 & 0.3 & 0.1 \\
\hline $\begin{array}{l}\text { permanent } \\
\text { blastula }\end{array}$ & \multirow{3}{*}{$12: 00$} & 21.7 & 23.5 & 19.1 & 2.0 & 2.3 & 1.0 & 0.8 & 0.9 & 0.8 & 0.9 & 1.1 & 0.8 \\
\hline gastrula & & 78.2 & 76.5 & 80.9 & 98.0 & 97.5 & 99.0 & 99.0 & 99.1 & 99.2 & 99.1 & 98.8 & 99.2 \\
\hline exogastrula & & 0.1 & 0.0 & 0.0 & 0.0 & 0.2 & 0.0 & 0.2 & 0.0 & 0.0 & 0.0 & 0.1 & 0.0 \\
\hline \multirow{2}{*}{$\begin{array}{l}\text { Indicatory } \\
\text { states }\end{array}$} & \multirow{2}{*}{$\begin{array}{l}\text { Time of } \\
\text { observ.* }\end{array}$} & \multicolumn{3}{|c|}{1.026} & \multicolumn{3}{|c|}{1.028} & \multicolumn{3}{|c|}{1.030} & \multicolumn{3}{|c|}{1.032} \\
\hline & & No. 1 & No. 2 & No. 3 & No. 1 & No. 2 & No. 3 & No. 1 & No. 2 & No. 3 & No. 1 & No. 2 & No. 3 \\
\hline $\begin{array}{l}\text { Formation of } \\
\text { fertiliz. memb. }\end{array}$ & $\begin{array}{c}\text { hr. min. } \\
0: 03\end{array}$ & $84.5 \%$ & $82.7^{\%}$ & $93.4^{\%}$ & $83.2^{\%}$ & $80.4^{\%}$ & $89.9^{\%}$ & $73.8^{\%}$ & $71.8^{\%}$ & $73.9^{\%}$ & $11.3^{\%}$ & $10.8^{\%}$ & $13.8^{\%}$ \\
\hline one cell & \multirow{3}{*}{$0: 45$} & 16.1 & 19.1 & 6.7 & 17.8 & 20.8 & 10.6 & 28.1 & 29.2 & 26.9 & 88.8 & 89.4 & 86.6 \\
\hline two cells & & 83.8 & 80.9 & 93.1 & 82.0 & 79.1 & 89.3 & 71.8 & 70.6 & 72.8 & 10.8 & 10.3 & 13.3 \\
\hline $\begin{array}{l}\text { multi-cells } \\
\text { (polyspermy) }\end{array}$ & & 0.1 & 0.0 & 0.2 & 0.2 & 0.1 & 0.1 & 0.1 & 0.2 & 0.3 & 0.4 & 0.3 & 0.1 \\
\hline $\begin{array}{l}\text { permanent } \\
\text { blastula }\end{array}$ & \multirow{3}{*}{$12: 00$} & 0.6 & 1.0 & 1.1 & 0.7 & 0.9 & 0.8 & 6.5 & 4.1 & 1.9 & 29.7 & 19.7 & 19.8 \\
\hline gastrula & & 99.3 & 99.0 & 98.8 & 99.1 & 99.0 & 99.2 & 93.3 & 95.8 & 97.8 & 70.2 & 80.3 & 80.2 \\
\hline exogastrula & & 0.1 & 0.0 & 0.1 & 0.2 & 0.1 & 0.0 & 0.2 & 0.1 & 0.3 & 0.1 & 0.0 & 0.0 \\
\hline
\end{tabular}

* After insemination., No. 1 to No. 3 are batch numbers of eggs.

+++ shows a full ripe state and ++ a ripe state of the gonad. 
Table 7. Effects of heavy metals upon the development of Anthocidaris crassispina eggs. Date: July 16-Aug. 7, 1970. Test water temperature: $28^{\circ} \mathrm{C}$

Original solution, chemicals 1:104 laboratory sea water. A in the column of "concentrations" shows the degree of dilution of the orignal solution by the volume in-original solution 1 : volume of sea water; B shows the same degree of dilution in $\mathrm{Mol}$ ratio; and $\mathrm{C}$ in the ratio of main effective component.

\begin{tabular}{|c|c|c|c|c|c|c|c|c|c|c|c|c|c|c|}
\hline \multirow{2}{*}{\multicolumn{4}{|c|}{ Chemicals }} & \multicolumn{3}{|c|}{ Concentrations } & \multirow{2}{*}{\begin{tabular}{l}
\multicolumn{1}{c}{$\begin{array}{c}3 \text { min. } \\
\text { after ins. }\end{array}$} \\
$\begin{array}{l}\text { Fertiliz. } \\
\text { membrane } \\
\text { formation } \%\end{array}$
\end{tabular}} & \multicolumn{3}{|c|}{45 min. after insemination } & \multicolumn{3}{|c|}{12 hrs. after insemination } & \multirow{2}{*}{$\begin{array}{l}\text { Ultimate } \\
\text { state of eggs }\end{array}$} \\
\hline & & & & A & B & $\mathrm{C}$ & & $\begin{array}{r}1-\text { cell } \\
\text { state } \\
\%\end{array}$ & $\mid$\begin{tabular}{c|}
2 -cell \\
state \\
$\%$
\end{tabular} & $\begin{array}{c}\text { Multi-cells } \\
\text { by } \\
\text { polyspermy } \\
\%\end{array}$ & $\begin{array}{c}\text { permanent } \\
\text { blastula } \\
\%\end{array}$ & $\begin{array}{r}\text { normal } \\
\text { gastrula } \\
\%\end{array}$ & $\begin{array}{l}\text { exo- } \\
\text { gastrula } \\
\%\end{array}$ & \\
\hline \multicolumn{4}{|c|}{ Control sea water } & & & & 95 & 6 & 94 & & & 100 & & normal \\
\hline \multirow{5}{*}{ 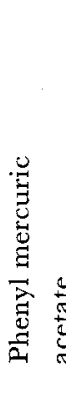 } & \multirow{5}{*}{ 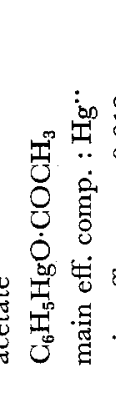 } & \multirow{5}{*}{ 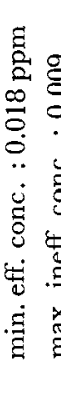 } & & 400 & 135 & 670 & 0 & 100 & & & & & & $\begin{array}{l}\text { unfertilized } \\
\text { cytolysis }\end{array}$ \\
\hline & & & & 800 & 270 & 1340 & 21 & 80 & 18 & 2 & & & & $\begin{array}{l}\text { cytolysis } \\
\text { (before } 32 \text { cells) }\end{array}$ \\
\hline & & & & 1600 & 540 & 2680 & 72 & 27 & 68 & 5 & 95 & 4 & 1 & $\begin{array}{l}\text { permanent } \\
\text { blastula }\end{array}$ \\
\hline & & & & 3200 & 1080 & 5360 & 86 & 16 & 82 & 2 & 86 & 12 & 2 & $\begin{array}{l}\text { permanent } \\
\text { blastula }\end{array}$ \\
\hline & & & & 6400 & 2160 & 10720 & 94 & 7 & 93 & & & 100 & & normal \\
\hline \multirow{5}{*}{\multicolumn{2}{|c|}{ 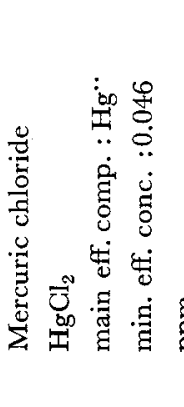 }} & \multirow{5}{*}{\multicolumn{2}{|c|}{ 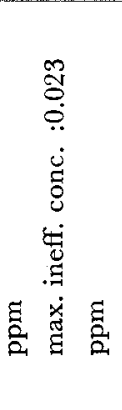 }} & 200 & 54 & 270 & 0 & 100 & & & & & & $\begin{array}{l}\text { unfertilized } \\
\text { cytolysis }\end{array}$ \\
\hline & & & & 400 & 108 & 540 & 6 & 95 & 4 & 1 & & & & $\begin{array}{l}\text { cytolysis } \\
\text { (before } 8 \text { cells) }\end{array}$ \\
\hline & & & & 800 & 216 & 1080 & 23 & 80 & 13 & 7 & & & & $\begin{array}{l}\text { cytolysis } \\
\text { (before } 32 \text { cells) }\end{array}$ \\
\hline & & & & 1600 & 432 & 2160 & 78 & 36 & 60 & 4 & 12 & 76 & 12 & $\begin{array}{l}\text { almost } \\
\text { normal }\end{array}$ \\
\hline & & & & 3200 & 864 & 4320 & 97 & 4 & 95 & 1 & & 100 & & normal \\
\hline
\end{tabular}




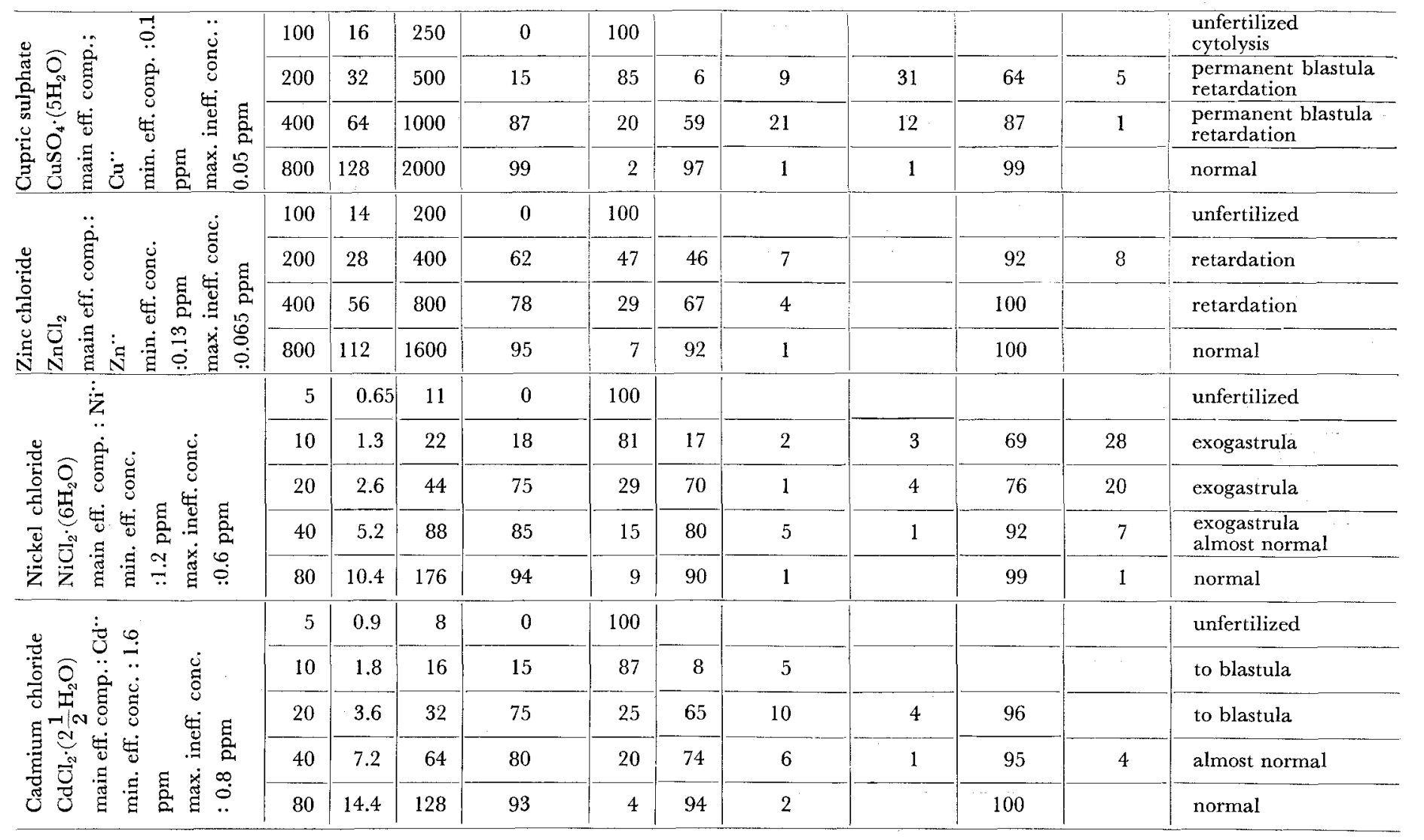




\begin{tabular}{|c|c|c|c|c|c|c|c|c|c|c|c|}
\hline \multirow[b]{2}{*}{ Chemicals } & \multicolumn{3}{|c|}{ Concentrations } & \multirow{2}{*}{\begin{tabular}{l}
\multicolumn{1}{c|}{$\begin{array}{l}3 \mathrm{~min} . \\
\text { after ins. }\end{array}$} \\
Fertiliz. \\
memtrane \\
formation $\%$
\end{tabular}} & \multicolumn{3}{|c|}{45 min. after insemination } & \multicolumn{3}{|c|}{$12 \mathrm{hrs}$ after insemination } & \multirow{2}{*}{$\begin{array}{l}\text { Ultimate } \\
\text { state of eggs }\end{array}$} \\
\hline & A & $\mathrm{B}$ & $\mathrm{C}$ & & $\begin{array}{c}1-\text { cell } \\
\text { state } \\
\%\end{array}$ & $\begin{array}{c}2-\text { cell } \\
\text { state } \\
\%\end{array}$ & $\begin{array}{c}\text { Multi-cells } \\
\text { by } \\
\text { polyspermy } \\
\%\end{array}$ & $\begin{array}{c}\text { permanent } \\
\text { blastula } \\
\%\end{array}$ & $\begin{array}{r}\text { normal } \\
\text { gastrula } \\
\%\end{array}$ & $\begin{array}{l}\text { exo- } \\
\text { gastrula } \\
\%\end{array}$ & \\
\hline \multirow{3}{*}{$\begin{array}{l}\text { Lead acetate } \\
\mathrm{Pb}\left(\mathrm{CH}_{3} \mathrm{COO}\right)_{2} \cdot\left(3 \mathrm{H}_{2} \mathrm{O}\right) \\
\text { main. eff. comp.: } \mathrm{Pb} \cdot \\
\text { min. eff. conc. }: 2.2 \mathrm{ppm} \\
\text { max. ineff. conc.: } 1.1 \mathrm{ppm}\end{array}$} & 20 & 4.4 & 22 & 0 & 100 & & & & & & cytolysis \\
\hline & 40 & 8.8 & 44 & 82 & 17 & 79 & 4 & 13 & 82 & 5 & retardation \\
\hline & 80 & 17.6 & 88 & 96 & 5 & 94 & 1 & & 100 & & normal \\
\hline \multirow{4}{*}{ 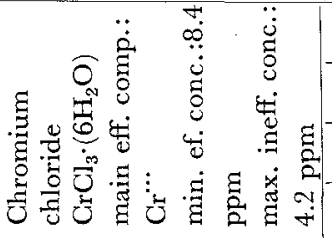 } & 1 & 0.16 & 3 & 0 & & & & & & & unfertilized \\
\hline & 2 & 0.32 & 6 & 74 & 26 & 71 & 3 & 66 & 27 & 7 & permanent blastula \\
\hline & 4 & 0.64 & 12 & 89 & 14 & 86 & & 5 & 93 & 2 & almost normal \\
\hline & 8 & 1.28 & 24 & 97 & 6 & 94 & & 2 & 98 & & normal \\
\hline \multirow{5}{*}{ 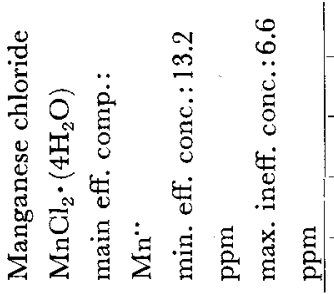 } & 0.4 & 0.05 & 0.92 & 0 & 100 & & & & & & cytolysis \\
\hline & 0.8 & 0.1 & 1.84 & 6 & 96 & 3 & 1 & & & & cytolysis \\
\hline & 1.6 & 0.2 & 3.68 & 64 & 36 & 62 & 2 & & & & $\begin{array}{l}\text { cytolysis } \\
\text { (before } 64 \text { cells) }\end{array}$ \\
\hline & 3.2 & 0.4 & 7.36 & 89 & 11 & 87 & 2 & 81 & 2 & 17 & $\begin{array}{l}\text { permanent blastula } \\
\text { exogastrula }\end{array}$ \\
\hline & 6.4 & 0.8 & 14.72 & 95 & 6 & 94 & & 3 & 96 & 1 & normal \\
\hline \multirow{4}{*}{ 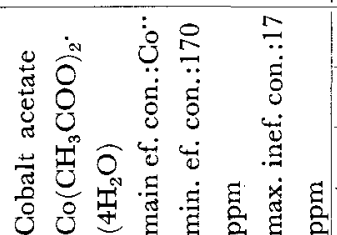 } & 0.002 & 0. & 0.006 & 0 & 100 & & & & & & unfertilized \\
\hline & 0.02 & 0.0035 & 0.06 & 2 & 99 & 1 & & & & & to $2-4$ cells \\
\hline & 0.2 & 0.035 & 0.6 & 74 & 33 & 65 & 2 & & & & to blastula \\
\hline & 2 & 0.35 & 6 & 94 & 7 & 93 & & & 99 & 1 & normal \\
\hline
\end{tabular}


mental stages of Anthocidaris crassispina eggs were checked separately. Though probably some of them will affect coactively in the sea, the first step must be to describe simply the effect of respective chemicals.

The chemicals to be tested were in the preliminary experiments made into a series of solutions by successive dilution by ten times of the original solution(chemicals 1: $10^{4}$ sea water). Thus, the gross concentration range in which some unusual features appeared on developing sea urchin eggs was found out first for respective chemicals. For the chemicals (some in Table 8) which have a wide range of concentrations for inhibitory effects, no further experiments will be needed. For other chemicals, however, the gross concentration range was then divided in further experiments into narrower grades by successive dilution by two times to see the inhibitory effects in more detail. Tables 7 and 8 show the results of some of preliminary and all of further experiments. The experiments were made in 23 days from July 16 to August 7 ; the test water temperature was nearly stable at $28^{\circ} \mathrm{C}$. The state of $A n$ tocidaris crassispina eggs was not uniform throughout this period, but the effect of respective chemicals could never be influenced seriously by the differences in the state of eggs, because the normal fertilization and development were achieved in the control in every experiment.

1. Heavy metals

It has been noted from old times that the sea water containing poisonous heavy metals, especially the water distributed through lead pipes or drawn up by metallic bucket is unavailable for normal fertilization and development of sea urchin eggs. On the other hand, there have been made many experiments with various heavy metals to induce such anomalies, in the fertilization and further development of urchin eggs, as polyspermy (Sugryama 1950, etc.) and exogastrulation (MaArthur 1924, Waterman 1937, etc.): in addition to these, inhibition of fertilization and further cleavages, and permanent blastula etc. are induced by some heavy metals. The present experiments were designed on the knowledges thus accumulated by previous researchers. In Tables 7 and 8 , the concentrations of chemicals are shown primarily by the dilution degree of the original solution (original solution 1: volume of sea water for dilution), in addition the same dilution degree is expressed similarly in the mol ratio (exclusive of the bound water) and ratio of the main effective ion or component of respective chemicals. The chemicals are arranged in the Table 7 in the order of inhibitory degrees on the fertilization and development of urchin eggs. The final state of eggs experimented with is described. The minimal effectual and maximal ineffectual concentrations are given in $\mathrm{ppm}$. The rate of the fertilization membrane formation 3 minutes after the insemination (exclusive of the formation of low fertilization membrane), the results of the cleavage 45 minutes after the insemination (undivided 1 -cell state, normal 2-cell state, and multi-cells caused by polyspermy), and the states of embryos 12 hours after the insemination (permanent blastula, normal gastrula, and abnormal exogastrula) were checked. As seen in Table 7, there 
Table 8. Effects of various chemicals other than heavy metals upont the development of Anthocidaris crassispina eggs. Date: July 16-Aug. 7, 1970. Test water temperature: $28^{\circ} \mathrm{C}$.

Original solution, chemicals $1: 10^{4}$ laboratory sea water. A in the column of "concentrations" shows the degree of

dilution of the original solution by the volume in-original solution 1: volume of sea water; B shows the same degree of dilution in Mol ratio; and $\mathrm{C}$ in the ratio of main effective component.

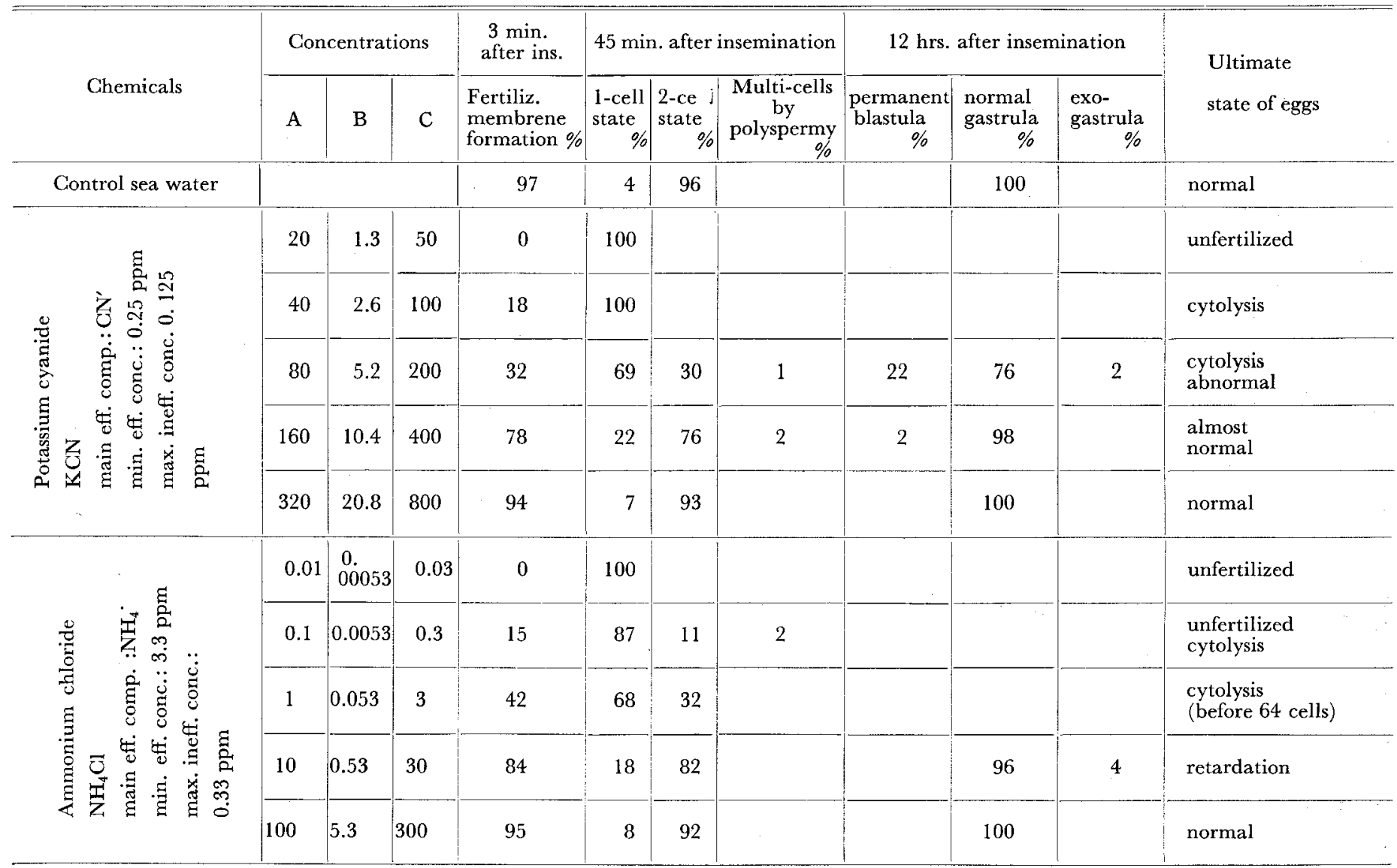




\begin{tabular}{|c|c|c|c|c|c|c|c|c|c|c|c|c|c|c|c|}
\hline \multirow{4}{*}{ 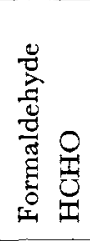 } & \multirow{4}{*}{ 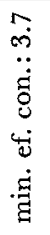 } & \multirow{4}{*}{ छ } & \multirow{4}{*}{ 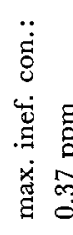 } & \multirow{4}{*}{$\frac{a}{2}$} & 0.1 & 0.003 & 0.27 & 0 & 100 & & & & & & cytolysis \\
\hline & & & & & 1 & 0.03 & 2.7 & 11 & 93 & 7 & & & & & $\begin{array}{l}\text { cytolysis } \\
\text { (before } 32 \text { cells) }\end{array}$ \\
\hline & & & & & 10 & 0.3 & 27 & 41 & 64 & 36 & & 43 & 57 & & $\begin{array}{l}\text { permanent blastula } \\
\text { retardation }\end{array}$ \\
\hline & & & & & 100 & $3 \cdot 2$ & 270 & 92 & 11 & 89 & & 9 & $9 \mathrm{I}$ & & almost normal \\
\hline \multirow{5}{*}{ 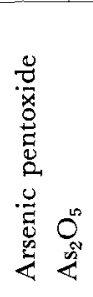 } & \multirow{5}{*}{ 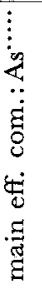 } & \multirow{5}{*}{ 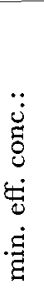 } & \multirow{5}{*}{ 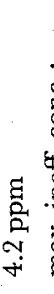 } & \multirow{5}{*}{ 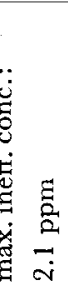 } & 1 & 0.23 & 3 & 0 & 100 & & & & & & cytolysis \\
\hline & & & & & 2 & 0.46 & 6 & 14 & 87 & 13 & & & & & $\begin{array}{l}\text { cytolysis } \\
\text { (before } 64 \text { cells) }\end{array}$ \\
\hline & & & & & 4 & 0.92 & 12 & 74 & 23 & 71 & 6 & & & & $\begin{array}{l}\text { cytolysis } \\
\text { (before blastula) }\end{array}$ \\
\hline & & & & & 8 & 1.84 & 24 & 86 & 16 & 83 & 1 & 4 & 96 & & almost normal \\
\hline & & & & & 16 & 3.68 & 48 & 95 & 6 & 94 & & & 100 & & normal \\
\hline \multirow{6}{*}{ 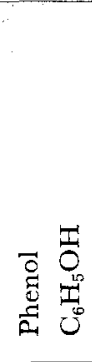 } & \multirow{6}{*}{\multicolumn{2}{|c|}{ 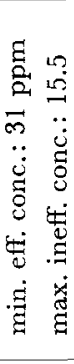 }} & \multirow{6}{*}{\multicolumn{2}{|c|}{ छ }} & 0.2 & 0.019 & & 0 & 100 & & & & & & unfertilized \\
\hline & & & & & 0.4 & 0.038 & & 7 & 95 & 5 & & & & & to blastula \\
\hline & & & & & 0.8 & 0.076 & & 31 & 79 & 21 & & 47 & 53 & & permanent blastula \\
\hline & & & & & 1.6 & 0.152 & & 65 & 44 & 54 & 2 & 18 & 77 & 5 & retardation \\
\hline & & & & & 3.2 & 0.304 & & 83 & 24 & 73 & 3 & 11 & 84 & 5 & retardation \\
\hline & & & & & 6.4 & 0.608 & & 95 & 9 & 91 & & & 99 & 1 & normal \\
\hline \multirow{4}{*}{ 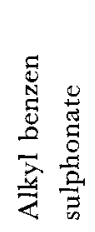 } & \multirow{4}{*}{$\begin{array}{l}\vec{m} \\
\ddot{g} \\
\dot{0} \\
\dot{0} \\
\dot{0} \\
\dot{g} \\
\dot{g}\end{array}$} & \multirow{4}{*}{\multicolumn{2}{|c|}{ 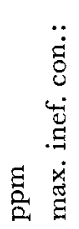 }} & \multirow{4}{*}{ 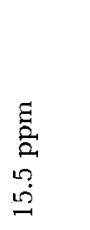 } & 0.4 & 0.174 & 0.8 & 0 & 100 & & & & & & unfertilized \\
\hline & & & & & 0.8 & 0.348 & 1.6 & 9 & 94 & 6 & & & & & retardation \\
\hline & & & & & 1.6 & 0.696 & 3.2 & 69 & 36 & 63 & 1 & & 100 & & almost normal \\
\hline & & & & & 3.2 & 1.392 & 6.4 & 95 & 6 & 93 & 1 & & 100 & & normal \\
\hline
\end{tabular}




\begin{tabular}{|c|c|c|c|c|c|c|c|c|c|c|c|}
\hline \multirow[b]{2}{*}{ Chemicals } & \multicolumn{3}{|c|}{ Concentrations } & \multirow{2}{*}{\begin{tabular}{|l|}
\multicolumn{1}{c|}{$\begin{array}{l}\text { after ins. } \\
\text { aftin. }\end{array}$} \\
Fertiliz. \\
membrene \\
formation $\%$
\end{tabular}} & \multicolumn{3}{|c|}{$45 \mathrm{~min}$. after insemination } & \multicolumn{3}{|c|}{12 hrs. after insemination } & \multirow{2}{*}{$\begin{array}{l}\text { Ultimate } \\
\text { state of eggs }\end{array}$} \\
\hline & $\mathrm{A}$ & $\mathrm{B}$ & $\mathrm{C}$ & & $\begin{array}{c}1-\text { cell } \\
\text { state } \\
\%\end{array}$ & $\begin{array}{c}2 \text {-cell } \\
\text { state } \\
\%\end{array}$ & $\begin{array}{c}\text { Multi-cells } \\
\text { by } \\
\text { polyspermy } \\
\%\end{array}$ & $\begin{array}{c}\text { permanent } \\
\text { blastula } \\
\%\end{array}$ & $\begin{array}{r}\text { normal } \\
\text { gastrula } \\
\%\end{array}$ & $\begin{array}{l}\text { exo- } \\
\text { gastrula } \\
\%\end{array}$ & \\
\hline \multirow{5}{*}{ 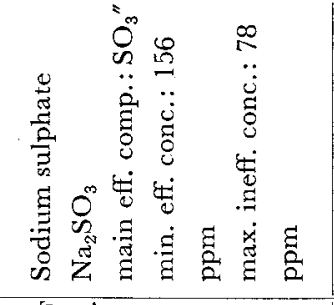 } & 0.05 & 0.0065 & 0.08 & 0 & 100 & & & & & & unfertilized \\
\hline & 0.1 & 0.013 & 0.16 & 21 & 97 & 3 & & & & & $\begin{array}{l}\text { cytolysis } \\
\text { (before } 64 \text { cells) }\end{array}$ \\
\hline & 0.2 & 0.026 & 0.32 & 26 & 84 & 14 & 2 & & & & $\begin{array}{l}\text { cytolysis } \\
\text { (before blastula) }\end{array}$ \\
\hline & 0.4 & 0.052 & 0.64 & 64 & 38 & 61 & 1 & 18 & 82 & & almost normal \\
\hline & 0.8 & 0.104 & 1.28 & 96 & 6 & 91 & 3 & & 100 & & normal \\
\hline \multirow{3}{*}{ 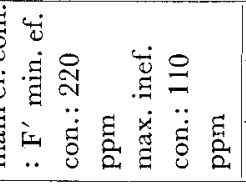 } & 0.1 & 0.004 & 0.22 & 0 & 100 & & & & & & unfertilized \\
\hline & 0.2 & 0.008 & 0.44 & 21 & 78 & 21 & 1 & & 99 & 1 & almost ncrmal \\
\hline & 0.4 & 0.016 & 0.88 & 98 & 2 & 98 & & & 100 & & normal \\
\hline \multirow{4}{*}{ 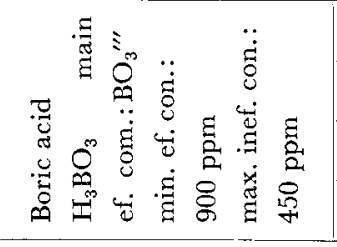 } & 0.025 & 0.0015 & 0.027 & 0 & 100 & & & & & & $\begin{array}{l}\text { unfertilized } \\
\text { cytolysis }\end{array}$ \\
\hline & 0.05 & 0.003 & 0.055 & 30 & 100 & & & & & & cytolysis \\
\hline & 0.1 & 0.006 & 0.11 & 54 & 51 & 45 & 4 & 26 & 72 & 2 & retardation \\
\hline & 0.2 & 0.012 & 0.22 & 97 & 6 & 94 & & & 100 & & normal \\
\hline
\end{tabular}


were found in some solutions some eggs in which no cleavage followed the formation of the fertilization membrane.

At higher concentrations of every chemical, the fertilization never occurred, all eggs remained as they were at the beginning of experiment or disintegrated. The lower the concentration was, the more the rate of fertilization was recovered, till the cleavage was regained. In a very wide range of concentration, however, the polyspermy appeared more or less; furthermore, the cleavage tended to stop at some stages or the development, when it continued, tended to be much retarded. At higher concentrations of certain heavy metals such as $\mathrm{Cu}, \mathrm{Cr}$, and $\mathrm{Mn}$, the fertilization membrane did not disappear even at the hatching of blastula; and this caused the partial escape of embryos, which never grew up normally.

The permanent blastula appeared at higher rates in the order from phenyl mercuric acetate down to manganese, chrome, to copper; and the exogastrula appeared especially at a high rate in the water including nickel. Throughout the effects of heavy metals upon the fertilization and development of urchin eggs the toxicity was seemingly higher in the order from $\mathrm{Hg}$ down to $\mathrm{Gu}, \mathrm{Zn}, \mathrm{Ni}, \mathrm{Cd}, \mathrm{Pb}, \mathrm{Cr}$, $\mathrm{Mn}$, to Co. On the other hand, the toxicity of phenyl mercuric acetate was stronger than that of mercuric chloride; the rates of permanent blastula and exogastrula differed greatly between these two chemicals. The permanent blastula appeared at very higher rate in phenyl mercuric acetate but not at so high rate in mercuric chloride, while the exogastrula occurred more abundantly in the latter than in the former. In general, it is obvious that the heavy metals induce polyspermy, permanent blastula, exogastrula and other anomalies. These results of the experiments conform exactly to those obtained by many researchers who tested long ago the effects of various heavy metals upon the fertilization and development of sea urchin eggs.

2. Other chemicals.

Various chemicals other than heavy metals were tested in the same way as in the case of metals, they are shown in Table 8 in the order of minimal concentration effective upon the fertilization and development of urchin eggs from potassium cyanide up to boric acid. Various chemicals have been known as poisonous, but generally the inhibitory effect was revealed in the highest grade in so-called poisons. The anomalies seen in the experiments were generally almost the same as in the case of heavy metals; but the polyspermy was less frequent but in arsenic acid and the exogastrulation was so, too, but in phenol, etc. The permanent blastula was induced as often as by heavy metals; it appeared markedly in the order from phenol down to formaldehyde, boric acid, to potassium cyanide. The retardation of growth was observed, too.

\section{Considerations}

As to the biological effect of a single chemical, WAtERMAn (1937) made a com- 
prehensive experiment with a series of metallic salts and reported that the relative toxicity of metallic salts was higher in the following order $\mathrm{HgCl}_{2}>\mathrm{CuCl}_{2}>\mathrm{ZnCl}_{2}$, $\mathrm{ZnSO}_{4}, \mathrm{Zn}\left(\mathrm{C}_{2} \mathrm{H}_{3} \mathrm{O}_{2}\right)_{2}>\mathrm{PbCl}_{2}>\mathrm{AlCl}_{6}, \mathrm{CdCl}_{2}, \mathrm{NiCl}_{2}>\mathrm{FeCl}_{2}$, and that in cases of most salts employed the initial effect was seen upon the growth and differentiation, retardation and inhibition became increasingly more conspicuous in progressively higher concentrations, and the gastrulation process was the last to be affected. In the present experiments, it was noted that some metallic salts, especially $\mathrm{NiCl}_{2}$, gave larger numbers of exogastrulae at certain concentrations than in some experiments made by previous researchers. The induction of polyspermy in the sea urchin eggs by $\mathrm{CuSO}_{4}$ was reported by Sugryama (1950); the reported concentration effective for induction almost agree with that shown in the present paper, only some difference being found in the rate of the occurrence of polyspermy. The lower rate in the present experiments may be attributable to the difference of the material urchin or to somewhat different experimental conditions.

Then, as to the actual bioassay of heavily polluted sea water, it must be noted that the inhibitory effect of the water from Osaka Bay was much decreased by boiling; this indicates that the effective pollutants in both water samples from Osaka Bay were largely evaporated or became biologically inactive by precipitation or by coherence to other substances by boiling. For volatile or evaporable substances, phenol, formaldehyde, and ammonia, etc. are thought of. But on the other hand, some of these substances may possibly become insoluble by boiling, as SiebUrth and Jensen (1969) mention about a few simple precurosrs of (potential) phenolic nature exuded from the brown seaweeds. It is stated by them that in the alkaline medium of sea water these exuded precursors form polyphenols which rapidly react with proteinaceous and carbohydrate material of either algal or other origin. The reactive polyphenols are noted to be toxic to some larval forms, but it is concluded that the resulting phenolic complexes make up a considerable part of harmless marine "Gelbstoff" (humic material) and contribute to form organic aggregates. Similar transformations of phenolic precursors to "Gelbstoff" and organic aggregates were found to take place in a sulphate paper mill effluent. Thus, the inhibitory effect of reactive polyphenol might be seen in some natural environments of a certain topography and hydrography. However, in the water samples from heavily polluted Osaka Bay, it is very possible that some heavy metals were contained and the metallic salts became insoluble or became harmless by coherence to other substances by boiling. The existence of a significant amount of phenol, formaldehyde and some heavy metals in the untreated sea water from Osaka Bay is very possible, though the indication of actually effective substances will be possible only when the crucial chemical analyses of the water are finished.

On the other hand, the inhibitory effect of the turbid water in the inner part of Tanabe Bay is seemingly not attributable to any heavy metals or such substances as phenol and formaldehyde; possibly the effect might be caused by ammonia-state 
nitrogen.

Historically, WiLson (1951) reported that the development of sea urchin eggs was influenced by some unknown property or properties of sea water, which was variable from one locality to another and even in the same station, would appear to be linked with the distribution and movements of oceanic and coastal water masses. Further, WiLson and ARMstrong (1952) described that the unknown composition to affect the development was extracted and that some changes of alkalinities had little or no effect on the development, that the bacteria-free water had no effect on the development of urchin eggs and the addition to the water of gonad extracts, filtered coelomic fluid or filtered sea water from dead or decayed urchin was detrimental to urchin larvae (1954), that a certain sea bottom water and mud extract were some time hramful to urchin eggs (1958), and that at higher levels of copper concentration urchin larvae were stunted in their growth, but copper in small amount was beneficial (1961). In conclusion, they stated that it seemed unlikely that one simple factor was responsible for biological differences between sea waters whenever and wherever they occurred, rather it might occur that a number of factors were operative, varying with time and place and thus the whole subject was probably more complex than previously had been thoguht. Although they have seemingly not thought of the pollution of the sea specially in doing the above-mentioned reseaches, the process of their successive works and the results of works are very suggestive of the bioassay for marine pollution and actually they form the standponit where my present studies have started from.

In applying the bioassay to perceive and measure the sea water pollution, Oкuвo and Окиво (1962) proposed the use of developing sea urchin eggs and embryos in 816 cell stages to pluteus and bivalve larvae as indicator organisms. Comparing the effects of various pollutants on these indicators with those learned by other methods of bioassay, they pointed out the advantages of their method as follows: the effects of pollutants on the development of eggs are easily recognizable as distinct features of disturbed metamorphosis; different larval organisms (four species, Hemicentrotus pulcherrimus, Anthocidaris crassispina, Crassostrea gigas, and Mytilus edulis, were tested) show a similar sensitivity to pollutants, thus it is possible that a similar bioassay method is available in any season of the year; the sensitivity of larval organisms tested to pollutants is much higher than that seen in other organisms; and the maximal concentrations of some pollutants ineffective to induce any morphological anomalies in the embryonic development of sea urchins and bivalves are seemingly directly equal to the safety level of the pollutant concentration for littoral fishes. The results of my experiments almost coincide with those of Oкuвo and Okuвo's as to the minimal effective concentrations of chemicals, although the indicatory stages to be checked differ between theirs and mine.

Recently WoELKe (1967) presented a very remarkable paper recommending the measurement of water quality with the bioassay using embryos of the Pacific oyster 
Crassostrea gigas (Thunberg). From the stand point of his view that standards or criteria should be based on biological measurements, if consumer needs are based on biological factors, areas of acceptable and unacceptable water quality have been delineated relative to oysters in a northern area of Washington State near Port Angeles. Throughout the data obtained in a series of toxicity bioassays conducted on pulp mill and oil refinery wastes and polluted estuarine water, it was indicated that the Pearl-Benson Index (PBI), a chemical measure commonly used for measuring pulp and paper wastes, did not measure the relative toxicity of the different wastes. While admitting that the results of oyster embryo bioassays can be used with a fair degree of confidence when difining water quality for molluscs, he warns against the extension of the results to crustaceans, fish or diatoms and other plankton forms.

In spite of Окиво and Окиво's statement that larvae of some different species of urchins and bivalves were similarly sensitive to pollutants and the maximal ineffective concentrations of some pollutants for urchin and bivalve larvae were available as the safety level for some fish, I am also very cautious to extend the results obtained using urchin eggs to other organisms. Evidently it must be unreasonable to apply the results here obtained directly to other organisms, but it seems very possible that some parallelism will be seen between the results obtained by using very different organisms.

Anyhow, the higher sensitivity of larval forms to different environmental factors has been noticed in many animals. For example, Regnault (1969) referred to a case that the larval development of Hippolyte inermis LeAcH (Decapoda, Natantia) was influenced differently by the origin of sea water used for the laboratory culture. Suguri (1970) indicated a sensitivity of abalone veligers to waste oils from petrochemical factories much higher than in adults. The use of bioassay to measure the water pollution and further the use of larval forms as indicator organisms for bioassay are becoming very popular.

As noted already by WOELKE on oyster embryos, its simplicity and easiness to treat the material and to define the effects, its speed, high sensitivity, uniformity, and its higher accuracy by checking a quantity are the advantages of the bioassay for marine pollution using sea urchin eggs and embryos. Moreover, the results are very similar between different species of urchins and this makes it possible that the same method is available throughout the year. Lastly, however, it is urged to define the charactersitic effecting pattern of respective pollutants on developing urchin eggs and embryos and to clear out the pattern of coaction between significant pollutants.

I wish to express my hearty thanks to the staff of the Seto Marine Biological Laboratory for the fund and facilities given to me in carrying out the researches at the Laboratory, particularly to Dr. Takashi Tokioka of the laboratory for advices and criticisms and for his kindness in reading the manuscript. My deep gratitude is also due to Prof. Masao Sugryama of Nagoya University for important suggestions and to 
the staff of the Guard and Rescue Section, Osaka Maritime Safety Station, for facilities in obtaining water samples in and around Osaka Harbour.

\section{Summary}

1. A series of bioassays were made to measure the marine pollution around Hatakejima Island, the experimental field of the Seto Marine Biological Laboratory.

2. Sea urchin eggs and embryos were used as indicator organisms: indicatory stages and states were normal fertilization and cleavages to gastrulation and such anomalies as polyspermic cleavage, permanent blastula and exogastrula.

3. The running sea water of the laboratory is seemingly at present free from any kind of pollutants. The water from the open-sea side of Hatakejima Island is almost pure, but the water from the land side of the island and the water from Tsunashirazu Gove are considerably polluted, especially markedly in the latter.

4. In the water samples from Osaka Harbour and from the estuary of the River Kizu, no fertilization of urchin eggs occurred. Only a small number of eggs were successfully fertilized and developed to gastrulae when the water density was raised up to the level of controls by addition of Jamarin, though the first cleavage was retarded by about 15 minutes and further delay of later development brought a very high percent of permanent blastula. The water from the estuary of the River Kizu was more polluted than the water from the harbour. The rates of fertilization and further development were much improved nearly to the level of the control when the density was recovered by boiling. The same rates in the boiled laboratory water were also somewhat depressed.

5. Heavy metals induce multi-cells, permanent blastula and exogastrula, etc. Various chemicals other than heavy metals induce the same phenomena, but generally less polyspermy and exogastrulation.

6. The bioassay to measure marine pollution using sea urchin eggs has such advantages as simplicity, easiness, speed, high sensitivity, clearness of indicatory features, uniformity, and higher accuracy. As different urchin species react to pollutants very similarly, the same method is available in any season of the year.

\section{REFERENCES}

Clark, J.M. 1936. An experimental study of polyspermy. Biol. Bull. 70: pp. 361-384.

Kobayashi, N. 1969. Spawning periodicity of sea urchins at Seto III. Sci. Eng. Rev. Doshisha Univ. 9: pp. $42-57$.

MacArthur, J.W. 1924. An experimental study and a physiological interpretation of exogastrulation and related modifications in echinoderm embryos. Biol. Bull. $46:$ pp. 60-87.

Окиво, K. and Окиво, T. 1962. Study on the bio-assay method for the evaluation of water pollution -II. Use of the fertilized eggs of sea urcins and bivalves. Bulletin, Tokai Regional Fisheries Research Laboratory 32: pp. 131-140.

Regnault, M. 1969. Influence de la temperature et de l'origine de l'eau de mer sur le developpement larvaire au laboratoire d'Hippolyte inermis Leach (Decapode-Natanita). Vie et Milieu Ser. A 20: pp. 137-152. 
Sieburth, J.M. and Jensen, A. 1969. Studies on algal substances in the sea. II. The formation of Gelbstoff (Humic material) by exudates of Phaeophyta. J. Exp. Mar. Biol. Ecol. 3: pp. 275-289.

Sugryama, M. 1950. Polyspermy in the sea-urchin eggs induced by $\mathrm{CuSO}_{4}$. Zool. Magz, 50: pp. 11-12.

Suguri, A. 1970. Preliminary experiments to measure the toxicity of waste oils from petrochemical factories to spiny lobsters and abalones. 1968 Reports from the Mie Prefectural Fisheries Experimental Station, Hamashima. pp. 367-368. (in Japanese)

Tokioka, T. 1969. Hetakezima island will successfully be conserved for marine biological researches. Publ. Seto Mar. Biol. Lab. 17: pp. 1-6.

Waterman, A.J. 1937. Effects of salts of heavy metals on development of the sea urchin, Arbacia punctulata. Biol. Bull. 73 : pp. 401-420.

Wilson, D.P. 1951. A biological differences between natural sea waters. J. Mar. Biol. Assoc. 30: pp. $1-26$.

Wilson, D.P. and Armstrong, F.A.J. 1952. Further experiments on biological differences between natural sea waters. J. Mar. Biol. Assoc. 31: pp. 335-349.

- 1954. Biological differences between sea waters: Experiments in 1953. J. Mar. Biol. Assoc. 33: pp. $347-360$.

- 1958. Biological differences between sea waters: Experiments in 1954 and 1955. J. Mar. Biol. Assoc. 37: pp. 331-348.

- 1961. Biological differences between sea waters: Experiments in 1960. J. Mar. Biol. Assoc. 41 : pp. 663-681.

Woelke, C.E. 1967. Measurement of water quality with the Pacific oyster embryo bioassay. Water Quality Criteria STP 416: pp. 112-120. 